\title{
PENERAPAN ASAS KEADILAN TERHADAP TINDAK PIDANA KEKERASAN DALAM RUMAH TANGGA BERDASARKAN UNDANG UNDANG NOMOR 23 TAHUN 2004 TENTANG PENGHAPUSAN KEKERASAN DALAM RUMAH TANGGA \\ ${ }^{1}$ Sofian Hadi, ${ }^{2}$ Dini Dewi Heniarti, ${ }^{3}$ Chepi Ali Firman Zakaria \\ Alumni Program Studi Magister Ilmu Hukum \\ Pascasarjana Universitas Islam Bandung \\ Email : ${ }^{1}$ sofyan_akang@yahoo.co.id, ${ }^{2}$ dini.dewiheniarti@gmail.com, \\ ${ }^{3}$ chepialifirmanzakaria@gmail.com
}

\begin{abstract}
Abstrak : Landasan sosiologis ditetapkannya UU Nomor 23 Tahun 2004 tentang Penghapusan Kekerasan dalam Rumah Tangga, yaitu karena tingginya tingkat kekerasan dalam rumah tangga, dimana ancaman pidananya sangat rendah, sehingga menimbulkan ketidakadilan bagi korban, khususnya istri. Sementara itu, dalam sistem hukum di Indonesia belum menjamin perlindungan terhadap korban kekerasan. Tujuan penelitian ini adalah untuk mengetahui penerapan asas keadilan terhadap tindak pidana kekerasan dalam rumah tangga berdasarkan UU Nomor 23 Tahun 2004, dan untuk mengetahui upaya meminimalisir tindak pidana kekerasan dalam rumah tangga sehingga dapat mencegah terjadinya perceraian. Metode yang digunakan dalam penelitian ini adalah metode yuridis normatif, metode analisis penelitian ini adalah yuridis kualitatif. Hasil dari penelitian ini adalah penerapan asas keadilan terhadap tindak pidana kekerasan dalam rumah tangga berdasarkan Undang Undang Nomor 23 Tahun 2004 harus dipenuhi 4 (empat) syarat, yaitu equality (kesamaan), certainty (kepastian hukum), arrangement (pengaturan), dan implementation (pelaksanaan). Upaya meminimalisir tindak pidana kekerasan dalam rumah tangga dalam mencegah terjadinya perceraian adalah harus menyentuh 3 (tiga) indikator, yaitu secara hukum, memaksimalkan peran subseksi hubungan masyarakat kepolisian bekerja sama dengan dinas kependudukan dan Kantor Urusan Agama, adanya program pemerintah dalam pencegahan terjadinya kekerasan dalam rumah tangga dan peningkatan kesadaran serta kepatuhan hukum perilaku masyarakat melalui peran aktif tokoh masyarakat.
\end{abstract}

Kata Kunci : Keadilan, Tindak Pidana, Kekerasan, Rumah Tangga.

Abstract: The sociological basis of the stipulation of Law Number 23 Year 2004
concerning the Elimination of Domestic Violence is because of the high level of domestic
violence, in which the threat of punishment is very low, causing injustice to victims,
especially wives. Meanwhile, the legal system in Indonesia does not yet guarantee
protection for victims of violence. Hence, this study was conducted to determine the
implementation of justice principle on criminal acts of domestic violence based on Law
Number 23 Year 2004, and to discover how to minimize criminal acts of domestic violence
to prevent divorce. The method used normative juridical method by using qualitative
juridical analysis. The result revealed that the implementation of justice principle on
criminal acts of domestic violence based on Law Number 23 Year 2004 must fulfilled four
conditions, namely equality, certainty, arrangement, and implementation. Efforts to
minimize criminal acts of domestic violence in preventing divorce must pertain three
indicators, namely legally maximizing the role of the public relations subsection of the
police in collaboration with the population service and the Office of Religious Affairs;
providing government programs in preventing the occurrence of domestic violence; and 
${ }^{1}$ Sofian Hadi, ${ }^{2}$ Dini Dewi Heniarti, ${ }^{3}$ Chepi Ali Firman Zakaria, Penerapan Asas Keadilan Terhadap Tindak...

increasing awareness and legal compliance with community behavior through the active role of community leaders.

Keywords: Justice, Criminal Acts, Violence, Household

\section{A. PENDAHULUAN}

Secara filosofis, pembentukan Undang-Undang Nomor 23 Tahun 2004 tentang Penghapusan Kekerasan dalam Rumah Tangga adalah untuk melindungi wanita atau ibu rumah tangga dari kekerasan dalam rumah tangga. Hal ini tertuang dalam pertimbangan hukum Undang-Undang Nomor 23 Tahun 2004, yang berbunyi:

"Bahwa setiap warga negara berhak mendapatkan rasa aman dan bebas dan segala bentuk kekerasan sesuai dengan falsafah Pancasila dan UndangUndang Dasar Negara Republik Indonesia Tahun 1945".

Dalam konsideran ini yang dilindunginya, yaitu warga negara. Warga negara termasuk di dalamnya wanita. Hak warga negara adalah untuk mendapatkan rasa aman dan bebas dari segala bentuk kekerasan dalam rumah tangga. Landasan yuridis, pembentukan UndangUndang Nomor 23 Tahun 2004 tentang Penghapusan Kekerasan

dalam Rumah Tangga adalah karena segala bentuk kekerasan, terutama kekerasan dalam rumah tangga, merupakan pelanggaran hak asasi manusia dan kejahatan terhadap martabat kemanusiaan serta bentuk diskriminasi yang harus dihapus. (Pertimbangan Hukum huruf c Undang-Undang Nomor 23 Tahun 2004 tentang Penghapusan Kekerasan Dalam Rumah Tangga).

Landasan

sosiologis

ditetapkannya Undang-Undang Nomor 23 Tahun 2004 tentang Penghapusan Kekerasan dalam Rumah Tangga, yaitu karena tingginya tingkat kekerasan dalam rumah tangga yang dilakukan oleh pelaku atau suami atau istri, di mana sanksi pidananya sangat rendah, sehingga menimbulkan ketidakadilan bagi korban, khususnya istri. Sementara itu, dalam sistem hukum di Indonesia belum menjamin perlindungan terhadap korban kekerasan dalam rumah tangga. (Pertimbangan Hukum huruf d 
${ }^{1}$ Sofian Hadi, ${ }^{2}$ Dini Dewi Heniarti, ${ }^{3}$ Chepi Ali Firman Zakaria, Penerapan Asas Keadilan Terhadap Tindak...

Undang-Undang Nomor 23 Tahun 2004 tentang Penghapusan Kekerasan Dalam Rumah Tangga).

Berdasarkan hal tersebut, maka terlihat bahwa Undang-Undang Nomor 23 Tahun 2004 tentang Penghapusan Kekerasan dalam Rumah Tangga menerapkan keadilan korektif dimana kedudukan orang dalam rumah tangga baik suami dan istri adalah sama tanpa dibedakan, sehingga ketika terjadi kekerasan, pelaku dapat dihukum dan korban mendapatkan perlindungan.

Walaupun sanksi pidana yang tercantum dalam Undang-Undang Nomor 23 Tahun 2004 tentang Penghapusan Kekerasan dalam Rumah Tangga cukup berat, namun permasalahan yang timbul adalah tindak pidana kekerasan yang dilakukan oleh pelaku tidak selamanya dapat diproses secara hukum, karena sifat atau ciri khas dari tindak pidana ini adalah sebagai delik aduan. (Pasal 51 Undang-Undang Nomor 23 Tahun 2004 tentang Penghapusan Kekerasan Dalam Rumah Tangga).

Yang termasuk tindak pidana kekerasan dalam rumah tangga dengan sifat delik aduan, yaitu:

1. tindak pidana kekerasan fisik;
2. tindak pidana kekerasan psikis; dan

3. tindak pidana kekerasan seksual yang dilakukan oleh suami terhadap istri atau sebaliknya.

Delik aduan adalah delik atau tidak pidana yang dilakukan oleh seseorang tidak akan diproses atau disidik oleh pihak penegak hukum tanpa adanya pengaduan, permintaan atau laporan dari pihak korban, dan pengaduan itu dapat dicabut, sedangkan delik biasa adalah suatu perbuatan pidana, di mana pihak kepolisian akan tetap melakukan penyidikan, walaupun tanpa adanya pengaduan dan pihak korban. Ini berarti bahwa penegak hukum aktif melakukan penyidikan terhadap tindak pidana tersebut. (Rodliyah dan Salim HS, 2017 : 256).

Adanya ketentuan bahwa tindak pidana kekerasan dalam rumah tangga merupakan delik aduan, maka hal tersebut dapat mengurangi rasa aman terhadap korban kekerasan dalam rumah tangga yang seharusnya Negara wajib turut aktif memberikan rasa perlindungan kepada warganya ketika terjadi tindak pidana. Hal tersebut dikarenakan adanya peran aktif dari korban untuk membuat pengaduan sebagai syarat penuntutan terhadap 
${ }^{1}$ Sofian Hadi, ${ }^{2}$ Dini Dewi Heniarti, ${ }^{3}$ Chepi Ali Firman Zakaria, Penerapan Asas Keadilan Terhadap Tindak...

tindak pidana kekerasan dalam rumah tangga, sedangkan pada umumnya, psikis korban masih dalam masa trauma yang tidak memungkinkan untuk mengadukan adanya tindak pidana kekerasan dalam rumah tangga. Hal yang berbeda terjadi pada Negara Norwegia yang memandang tindak pidana kekerasan dalam rumah tangga sebagai delik aduan relatif.

Delik aduan relatif adalah kejahatan yang pada dasarnya bukan berupa kejahatan aduan, melainkan dalam hal-hal atau keadaan tertentu saja kejahatan itu menjadi kejahatan aduan. (Adam Chazawi, 2007 : 203204).

Hanya karena adanya unsurunsur tertentu saja, syarat pengaduan untuk melakukan penuntutan diperlukan, sedangkan dalam keadaan biasa artinya tanpa adanya unsur tertentu, syarat pengaduan tidak diperlukan untuk melakukan penuntutan.

Dalam hal tindak pidana kekerasan dalam rumah tangga, delik aduan relatif sekiranya memang ada alasan cukup kuat untuk melindungi kepentingan pribadi/keluarga. Relativitasnya bukan berarti digantungkan kepada kepentingan individu yang bersangkutan (pihak suami/istri), tetapi hendaknya diorientasikan/digantungkan kepada kepentingan masyarakat. Kebijakan dalam merumuskan delik aduan relatif yang berorientasi pada kepentingan umum seperti terdapat dalam KUHP Norwegia dapat kiranya dijadikan contoh, jadi disini tetap diperhatikan asas keseimbangan antara kepentingan individu dan kepentingan masyarakat. (Barda Nawawi Arief, 2011 : 281288).

\begin{tabular}{|c|c|}
\hline \multicolumn{2}{|c|}{ Kasus Kekerasan Terhadap Perempuan } \\
\hline $\begin{array}{l}\text { TAHUN } \\
2017\end{array}$ & Tahun 2016 \\
\hline $\begin{array}{l}259.150 \\
\text { Kasus }\end{array}$ & $\begin{array}{lrr}245.548 & \text { Kasus } & \text { yang } \\
\text { ditangani } & \text { oleh } & 359 \\
\text { Pengadilan } & \text { Agama } & \end{array}$ \\
\hline & $\begin{array}{l}\text { 13.602 Kasus yang ditangan } \\
\text { oleh } 233 \text { lembaga mitra } \\
\text { pengada layanan }\end{array}$ \\
\hline
\end{tabular}

Sumber: Komnas Perempuan Tahun 2017

Lihat:https://www.komnasperempuan. go.id/file/pdf_file/2017\%20Siaran\%2 OPers/Lembar\%20Fakta\%20Catahu\% 202017.pdf., diakses pada tanggal 4 Oktober 2018).

Kemudian terdapat peningkatan kasus kekerasan terhadap istri yang berujung pada perceraian pada tahun 2018, dimana berdasarkan Catatan Tahunan (CATAHU) Komnas 
${ }^{1}$ Sofian Hadi, ${ }^{2}$ Dini Dewi Heniarti, ${ }^{3}$ Chepi Ali Firman Zakaria, Penerapan Asas Keadilan Terhadap Tindak...

Perempuan Tahun 2018 dinyatakan bahwa terdapat 335.062 kasus kekerasan terhadap istri yang berujung pada perceraian. (Catatan Tahunan CATAHU Komnas Perempuan Tahun 2018, Jakarta, 7 Maret 2018, Hlm. 1. Lihat:

https://www.komnasperempuan.go.id/ file/pdf_file/2018/SIARAN\%20PERS \%202018/Lembar\%20Fakta\%20Catah u\%207\%20Maret\%202018.pdf., diakses pada tanggal 4 Oktober 2018).

Namun demikian, dari banyaknya kasus KDRT tersebut, hanya sedikit yang ditangani sampai ke tingkat pengadilan. Berdasarkan laporan LBH Apik, diketahui bahwa LBH Apik menerima aduan sebanyak 308 kasus kekerasan dalam rumah tangga (KDRT) sepanjang tahun 2017. Dari 308 kasus hanya 17 kasus yang berhasil diputus di Pengadilan. (https://news.detik.com/berita/386710 6/lbh-apik-terima-aduan-308-kdrtselama-2017, diakses pada tanggal 4 Oktober 2018).

Minimnya kasus diputus di Pengadilan disebabkan sebagian besar korban enggan mengadukan kasusnya ke tingkat Pengadilan. Korban enggan mengadu ke polisi karena masih ingin bermediasi dengan pasangan, lambatnya penanganan perkara, minimnya keadilan yang diterima korban selama proses pengadilan seperti tidak mendapatkan restitusi dan mahalnya biaya perkara. (Ibid) Hal tersebut sebagaimana data perkara KDRT tahun 2016 sampai dengan tahun 2018 yang digambarkan dalam tabel di bawah ini:

Tabel 1

Data Perkara KDRT di Pengadilan Negeri

Kota Kendari Tahun 2016 sampai 2018

\begin{tabular}{|c|c|c|c|}
\hline No. & Nama & Pasal & Putusan \\
\hline 1. & $\begin{array}{l}\text { Gatot } \\
\text { Susanto }\end{array}$ & $\begin{array}{l}\text { Pasal } 44 \\
\text { ayat (1) } \\
\text { UU No. } \\
23 \\
\text { Tahun } \\
2014 .\end{array}$ & $\begin{array}{c}1 \text { bulan } 15 \\
\text { hari }\end{array}$ \\
\hline 2. & Ruliansyah & $\begin{array}{l}\text { Pasal } 44 \\
\text { ayat (1) } \\
\text { UU No. } \\
23 \\
\text { Tahun } \\
2014 .\end{array}$ & $\begin{array}{c}3 \text { bulan } 7 \\
\text { hari }\end{array}$ \\
\hline 3. & $\begin{array}{l}\text { Herman alias } \\
\text { Emeng }\end{array}$ & $\begin{array}{l}\text { Pasal } 44 \\
\text { ayat (1) } \\
\text { UU No. } \\
23 \\
\text { Tahun } \\
2014 .\end{array}$ & 4 bulan \\
\hline 4. & $\begin{array}{l}\text { Nurul Iwan } \\
\text { Wahyudi }\end{array}$ & $\begin{array}{l}\text { Pasal } 44 \\
\text { ayat (1) } \\
\text { UU No. } \\
23 \\
\text { Tahun }\end{array}$ & 5 bulan \\
\hline
\end{tabular}




\begin{tabular}{|c|c|c|c|}
\hline & & 2014. & \\
\hline 5. & Munalisa & $\begin{array}{l}\text { Pasal } 44 \\
\text { ayat (1) } \\
\text { UU No. } \\
23 \\
\text { Tahun } \\
2014 .\end{array}$ & 5 bulan \\
\hline 6. & $\begin{array}{l}\text { Maode Muh. } \\
\text { Rasyid }\end{array}$ & $\begin{array}{l}\text { Pasal } 44 \\
\text { ayat (1) } \\
\text { UU No. } \\
23 \\
\text { Tahun } \\
2014 .\end{array}$ & 5 bulan \\
\hline $\begin{array}{l}\text { Sum } \\
\text { Kot: }\end{array}$ & $\begin{array}{l}\text { er: Data Perk } \\
\text { Kendari Tahur }\end{array}$ & $\begin{array}{l}\text { ra Pengac } \\
2016 \text { sar }\end{array}$ & $\begin{array}{ll}\text { an } & \text { Negeri } \\
\text { ai } & \text { dengan }\end{array}$ \\
\hline
\end{tabular}

Berdasarkan data di atas, maka terlihat bahwa Jaksa Penuntut Umum hanya menuntut pelaku saja dalam tindak pidananya, tanpa memikirkan kondisi korban yang tentunya membutuhkan bantuan baik materi maupun non materi. Bantuan untuk korban dapat diberikan dalam bentuk restitusi yang dibebankan kepada pelaku. Namun sayangnya, berdasarkan data penelitian yang Penulis peroleh, diketahui bahwa dakwaan JPU, tidak ada satupun tuntutan berupa restitusi terhadap korban.

Mengacu pada latar belakang permasalah yang telah diuraikan sebelumnya, pokok permasalahan yang akan dibahas ialah:
1. Bagaimanakah penerapan asas keadilan terhadap tindak pidana kekerasan dalam rumah tangga berdasarkan Undang Undang Nomor 23 Tahun 2004 tentang Penghapusan Kekerasan Dalam Rumah Tangga?

2. Bagaimana upaya penegakan hukum yang memberikan keadilan bagi para pihak terhadap tindak pidana kekerasan dalam rumah tangga sehingga dapat mencegah terjadinya perceraian?

\section{Metode Penelitian}

Penelitian ini termasuk dalam bentuk penelitian yuridis normatif, yaitu penelitian yang memberi pemahaman terhadap permasalahan norma yang dialami oleh ilmu hukum dogmatif dalam kegiatannya mendeskripsikan norma hukum, merumuskan norma hukum (membentuk peraturan perundang-undangan), dan menegakkan norma hukum (praktik yudisial). (I Made Pasek Diantha, 2016 : 84). Dalam penelitian ini, Penulis menggunakan data sekunder, oleh karena data sekunder pada umumnya ada dalam keadaan siap (ready-made) dan dapat diperoleh tanpa terikat atau dibatasi oleh waktu dan tempat. 
${ }^{1}$ Sofian Hadi, ${ }^{2}$ Dini Dewi Heniarti, ${ }^{3}$ Chepi Ali Firman Zakaria, Penerapan Asas Keadilan Terhadap Tindak...

(Soerjono Soekanto dan Sri Mamudji, 2006 : 24). Data yang diperoleh akan dianalisis secara analisis deskriptif kualitatif.

\section{B. PEMBAHASAN}

\section{Penerapan Asas Keadilan Terhadap Tindak Pidana Kekerasan Dalam Rumah Tangga Berdasarkan Undang Undang Nomor 23 Tahun 2004 \\ Tentang \\ Penghapusan \\ Kekerasan Dalam Rumah \\ Tangga}

Undang-Undang No. 23

Tahun 2004 tentang Penghapusan

Kekerasan Dalam Rumah Tangga muncul diawali dari kekerasan dalam rumah tangga (KDRT) yang salah satunya dipicu oleh penyelesaian berupa kekerasan/ pemukulan kepada isteri yang meninggalkan bekas luka fisik. Undang-Undang No. 23 Tahun 2004 tentang Penghapusan Kekerasan Dalam Rumah Tangga bertujuan untuk melindungi hakhak korban kekerasan khususnya perempuan. Di samping itu, Undang-Undang No. 23 Tahun 2004 tentang Penghapusan Kekerasan Dalam Rumah Tangga secara tidak langsung membahas tentang masalah privat khususnya masalah rumah tangga yang dulunya tidak disinggung sama sekali oleh undang-undang pidana.

Melihat ketentuan UndangUndang No. 23 Tahun 2004 tentang Penghapusan Kekerasan Dalam Rumah Tangga yang mengatur tentang perlindungan terhadap hak-hak korban kekerasan dalam rumah tangga, memperlihatkan bahwa pemerintah telah menerapkan prinsip keadilan dengan memberlakukan ketentuan pidana terhadap pelaku kekerasan dalam rumah tangga.

Menurut Penulis, asas keadilan adalah dalam kondisi yang sama antara anggota keluarga, baik istri maupun suami, sehingga tidak boleh berlaku sewenang-wenang terhadap anggota keluarga. Berdasarkan hal tersebut, maka apakah yang menjadi parameter terakomodasinya prinsip keadilan di dalam Undang-Undang No. 23 Tahun 2004 tentang Penghapusan Kekerasan Dalam Rumah Tangga.

Menurut

Penulis sebagaimana yang diungkapkan oleh Plato, Bernard L. Tanya, 2010 : 53). Akomodasi asas atau prinsip keadilan terhadap tindak pidana 
${ }^{1}$ Sofian Hadi, ${ }^{2}$ Dini Dewi Heniarti, ${ }^{3}$ Chepi Ali Firman Zakaria, Penerapan Asas Keadilan Terhadap Tindak...

kekerasan dalam rumah tangga terlihat pada saat dimulainya penyusunan Undang-Undang No. 23 Tahun 2004 tentang Penghapusan Kekerasan Dalam Rumah Tangga yang harus dipenuhi 4 (empat) syarat, yaitu:

a. Equality atau kesamaan, mengandung arti bahwa keadaan yang sama atau orang yang berada dalam keadaan yang sama.

Dalam asas 'equality' ini tidak diperbolehkan baik suami atau istri melakukan kekerasan dalam rumah tangga. Hal tersebut sebagaimana dinyatakan dalam Pasal 3 Undang-Undang No. 23 Tahun 2004 tentang Penghapusan Kekerasan Dalam Rumah Tangga yang menyatakan:

"Penghapusan kekerasan dalam rumah tangga dilaksanakan berdasarkan asas:

a. penghormatan hak asasi manusia;

b. keadilan dan kesetaraan gender;

c. nondiskriminasi; dan

d. perlindungan korban."
Selain daripada itu, dalam Pasal 5 Undang-Undang No. 23 Tahun $2004 \quad$ tentang Penghapusan Kekerasan Dalam Rumah Tangga menyatakan:

"Setiap orang dilarang melakukan kekerasan dalam rumah tangga terhadap orang dalam lingkup rumah tangganya, dengan cara:

a. kekerasan fisik;

b. kekerasan psikis;

c. kekerasan seksual; atau

d. penelantaran rumah tangga."

Pelanggaran

atas

ketentuan tersebut diatur dalam Pasal 44 Undang-Undang No. 23 Tahun 2004 tentang Penghapusan Kekerasan Dalam Rumah Tangga yang ancaman hukumannya adalah pidana penjara maksimal 15 (lima belas) tahun atau denda paling banyak Rp 45.000.000,00 (empat puluh lima juta rupiah), dimana ketentuan tersebut dapat dilakukan berdasarkan laporan dari korban kekerasan dalam rumah tangga atau umum disebut dengan delik aduan. Berdasarkan hal tersebut, maka 
baik suami ataupun istri memiliki perlindungan dan akibat hukum yang sama ketika salah satunya melakukan kekerasan dalam rumah tangga.

b. Certainty atau kepastian hukum, adalah tujuan setiap undangundang.

Kepastian hukum adalah suatu jaminan yang diberikan oleh Negara terhadap hak dan kewajiban dari setiap subjek hukum, melalui peraturan perundang-undangan yang di dalamnya tidak terdapat keterangan-keterangan yang saling bertentangan (kontradiksi atau inkonsistensi), baik secara vertikal maupun horizontal dan tidak terdapat pengertianpengertian atau istilah-istilah yang dapat diartikan secara berlainan, sehingga setiap subjek hukum akan memperoleh akibat hukum yang dikehendaki dalam suatu peristiwa hukum tertentu. (Edi Setiadi dan Kristian, 2017 : 189).

$$
\text { Dalam Undang-Undang }
$$

No. 23 Tahun 2004 tentang Penghapusan Kekerasan Dalam Rumah Tangga yang baik senantiasa dapat memberikan kepastian hukum kepada setiap orang dalam rumah tangga, apa hak-hak dan kewajiban mereka, siapa subjek dan objek. Di dalam ketentuan pidana Undang-Undang No. 23 Tahun 2004 tentang Penghapusan Kekerasan Dalam Rumah Tangga, diketahui bahwa pada umumnya, kasus kekerasan dalam rumah tangga merupakan delik aduan.

Hal tersebut dikarenakan para pembuat undang-undang, yaitu DPR dengan pemerintah berkeinginan bahwa sanksi pidana merupakan upaya terakhir (ultimatum remedium) apabila perdamaian tidak dapat dilakukan, sehingga tercipta "pidana keseimbangan" yaitu menindak pelaku KDRT di satu sisi, tetapi secara bersamaan ingin memelihara keutuhan rumah tangga. (Fatahillah A. Syukur, 2011 : 48). Hal tersebut sesuai dengan Pertimbangan Undang-Undang No. 23 Tahun 2004 tentang Penghapusan Kekerasan Dalam Rumah Tangga, dinyatakan tentang hak setiap orang, bahwa setiap warga negara berhak 
${ }^{1}$ Sofian Hadi, ${ }^{2}$ Dini Dewi Heniarti, ${ }^{3}$ Chepi Ali Firman Zakaria, Penerapan Asas Keadilan Terhadap Tindak...

mendapatkan rasa aman dan

bebas dari segala bentuk kekerasan sesuai dengan falsafah Pancasila dan UndangUndang Dasar Negara Republik Indonesia Tahun 1945, sehingga segala bentuk kekerasan, terutama kekerasan dalam rumah tangga, merupakan pelanggaran hak asasi manusia dan kejahatan terhadap martabat kemanusiaan serta bentuk diskriminasi.

c. Arrangement atau pengaturan, mengandung arti bahwa Undang-Undang No. 23 Tahun 2004 tentang Penghapusan Kekerasan Dalam Rumah Tangga telah mengatur dengan baik kepada pelaku kekerasan dalam rumah tangga terkait dengan akibat hukum atas tindakan melakukan kekerasan dalam rumah tangga. Tujuan dari adanya pengaturan tersebut adalah sebagai upaya menciptakan kepastian hukum.

d. Implementation atau pelaksanaan, mengandung arti bahwa dalam setiap penanganan kasus kekerasan dalam rumah tangga selalu mengikuti amanat dalam Undang-Undang No. 23
Tahun 2004 tentang Penghapusan Kekerasan Dalam Rumah Tangga.

Aspek keadilan di dalam pembentukan undang-undang secara umum harus melandasi setiap perumusan ketentuan perundang-undangan yang berlaku. Dalam hal ini, prinsip keadilan tercermin pada asas perlakuan yang sama dalam hukum (het rechtgelijkheidbrginsel) yang merupakan salah satu dari lima asas material yang wajib dipenuhi oleh peraturan perundang-undangan sebagaimana dikemukakan oleh Van der Vlies. I.C van der Vlies mengatakan asas-asas pembentukan peraturan perundang-undangan dapat dibagi menjadi dua, yaitu asas formal dan asas materiil. (Ibid)

Asas formal mencakup:

a. Asas tujuan yang jelas (beginsel van duetlijke doelstelling);

b. Asas organ / lembaga yang tepat (beginsel van het juiste organ);

c. Asas perlu pengaturan (het noodzakelijkheids beginsel);

d. Asas dapat dilaksanakan (het beginsel van uitvoorbaarheid); 
e. Asas konsensus (het beginsel van consensus). (Ibid)

Dalam asas materiil adalah sebagai berikut:

a. Asas terminologi dan sistimatika yang benar (het beginsel van duitdelijke terminologie en duitdelijke systematiek),

b. Asas dapat dikenali (het beginsel van de kenbaarheid);

c. Asas perlakuan yang sama dalam hukum (het rechsgelijkheids beginsel);

d. Asas kepastian hukum (het rechtszekerheidsbeginsel);

e. Asas pelaksanaan hukum sesuai dengan keadaan individual (het beginsel van de individuale rechtsbedeling). (Ibid)

Di samping pada saat penyusunan regulasinya, akomodasi asas atau prinsip keadilan juga dinilai penting pada saat penanganan kasus kekerasan dalam rumah tangga itu sendiri. Menurut Penulis, pengaturan kekerasan dalam rumah tangga harus dapat memberikan jaminan hukum bagi tercapainya keadilan, dan jaminan ini diberikan kepada pihak-pihak yang tersangkut di dalam kasus kekerasan dalam rumah tangga, baik yang dilakukan oleh suami maupun istri.

Penulis berpendapat, agar dapat terpenuhi asas keadilan, maka penanganan kasus kekerasan dalam rumah tangga harus menerapkan suatu pola penyelenggaraan yang diselenggarakan secara umum dan merata. Artinya, seluruh pelaku dan korban kekerasan dalam rumah tangga, baik suami maupun istri memiliki hak dan kewajiban yang sama tanpa ada perbedaan gender. Namun demikian, terdapat kelemahan dalam Undang-Undang No. 23 Tahun 2004 tentang Penghapusan Kekerasan Dalam Rumah Tangga, yaitu tidak adanya pengaturan tentang pemberian restitusi terhadap korban KDRT dan penjatuhan sanksi restitusi kepada pelaku KDRT.

Hal tersebut mengakibatkan ketidakadilan bagi korban KDRT, dimana selain menanggung beban penderitaan secara psikis, korban KDRT juga menanggung beban materiil, sebab biaya perawatan dan pemulihan korban biasanya membutuhkan banyak biaya, apalagi jika korban sampai terganggu jiwanya. Walaupun 
${ }^{1}$ Sofian Hadi, ${ }^{2}$ Dini Dewi Heniarti, ${ }^{3}$ Chepi Ali Firman Zakaria, Penerapan Asas Keadilan Terhadap Tindak...

Undang-Undang No. 23 Tahun 2004 tentang Penghapusan Kekerasan Dalam Rumah Tangga tidak mengatur secara eksplisit terkait dengan pemberian restitusi kepada korban KDRT, namun demikian, terdapat beberapa peraturan perundang-undangan yang mengatur pemberian restitusi kepada korban KDRT seperti Undang-Undang Nomor 31 Tahun 2014 Tentang Perubahan Atas Undang-Undang Nomor 13 Tahun 2006 Tentang Perlindungan Saksi dan Korban yang memberikan kewenangan kepada LPSK untuk memfasilitasi korban KDRT untuk mendapatkan restitusi dari pelaku KDRT, dan apabila korban KDRT adalah anak-anak, maka pengaturannya dapat dilakukan berdasarkan Undang-Undang Nomor 17 Tahun 2016 Tentang Perubahan Kedua Atas UndangUndang Nomor 23 Tahun 2002 Tentang Perlindungan Anak.

2. Upaya penegakan hukum yang memberikan keadilan bagi para pihak terhadap tindak pidana kekerasan dalam rumah tangga sehingga dapat mencegah terjadinya perceraian
Penegakan hukum tindak pidana kekerasan dalam rumah tangga pada umumnya tidak berjalan dengan baik. Hal tersebut sebagaimana yang diutarakan dalam Catatan Tahunan (CATAHU) Komnas Perempuan Tahun 2018 dinyatakan bahwa pada umumnya korban tidak mau melaporkan kasus kekerasan dalam rumah tangganya dikarenakan takut aibnya diketahui orang, dan juga adanya tekanan dari keluarga untuk tidak perlu melaporkan kasusnya, (Catatan Tahunan CATAHU Komnas Perempuan Tahun 2018, Jakarta, 7 Maret 2018, Hlm. 1. Lihat:

https://www.komnasperempuan.go. id/file/pdf_file/2018/SIARAN\%20 PERS\%202018/Lembar\%20Fakta \%20Catahu\%207\%20Maret\%2020 18.pdf., diakses pada tanggal 4 Oktober 2018). Sehingga membuat efektifitas penegakan hukum tidak berjalan dengan baik.

Penulis berpendapat, untuk menjawab permasalahan ini, maka diperlukan teori sistem hukum dari Lawrence M. Friedman. Dalam proses penegakan hukum, perlu dipahami, bahwa aturan hukum 
${ }^{1}$ Sofian Hadi, ${ }^{2}$ Dini Dewi Heniarti, ${ }^{3}$ Chepi Ali Firman Zakaria, Penerapan Asas Keadilan Terhadap Tindak...

bersifat memaksa, dalam pengertian, memaksa dari segi-segi kehadiran hukum itu sebagai instrumen untuk menertibkan dan membangun masyarakat. Memaksa juga dalam pengertian masyarakat harus menerima dan mengetahui kehadiran hukum itu untuk mengatur dirinya, karena hukum itu adalah sistem aturan dan prosedur untuk melindungi, mengatur dan merekayasa masyarakat. (Sri Rahayu Oktoberina, 2008 : 26).

Menurut Friedmann, sistem hukum terdiri dari tiga elemen, yaitu elemen struktur (structure), substansi (substance) dan budaya hukum (legal culture). (Lawrence M Friedman, 1967 : 14).

Berdasarkan hal tersebut, maka faktor penentu efektifitas penegakan hukum tindak pidana kekerasan dalam rumah tangga adalah sebagai berikut:

\section{a. Faktor Substansi Hukum} (Substance)

Elemen kedua dari sistem hukum adalah substansi hukum (substance).

Penjelasan

Friedman terhadap substansi hukum adalah sebagai berikut:

"By this is meant the actual rules, norms, and behavior patterns of people inside the system. This is, first of all, "the law "in the popular sense of the term-the fact that the speed limit is fifty-five miles an hour, that burglars can be sent to prison, that 'by law' a pickle maker has to list his ingredients on the label of the jar".

Berdasarkan hal tersebut, Friedman mengatakan bahwa yang dimaksudkan dengan substansi hukum adalah peraturan-peraturan yang ada, norma-norma dan aturan tentang perilaku manusia, atau yang biasanya dikenal orang sebagai "hukum" itulah substansi hukum. Penulis berpendapat, secara normatif, UndangUndang No. 23 Tahun 2004 tentang Penghapusan Kekerasan Dalam Rumah Tangga sudah sangat baik dalam pengaturannya.

Pembuat undang-undang, yaitu DPR dengan pemerintah mengatur bahwa tindak pidana kekerasan dalam rumah tangga dibuat sebagai delik aduan, oleh 
${ }^{1}$ Sofian Hadi, ${ }^{2}$ Dini Dewi Heniarti, ${ }^{3}$ Chepi Ali Firman Zakaria, Penerapan Asas Keadilan Terhadap Tindak...

karena berkeinginan bahwa

sanksi pidana merupakan upaya

terakhir (ultimatum remedium)

apabila perdamaian tidak dapat

dilakukan, sehingga tercipta

"pidana keseimbangan" yaitu menindak pelaku KDRT di satu sisi, tetapi secara bersamaan ingin memelihara keutuhan rumah tangga sebagaimana Pertimbangan Undang-Undang No. 23 Tahun 2004 tentang Penghapusan Kekerasan Dalam Rumah Tangga. (Fatahillah A. Syukur, Loc.Cit).

Berdasarkan hal tersebut, menurut Penulis, diperlukan peran dari subseksi Hubungan Masyarakat dari Kepolisian bekerja sama dengan Dinas Kependudukan dan KUA dalam mensosialisasikan setiap peraturan perundang-undangan berkaitan dengan Penghapusan Kekerasan Dalam Rumah Tangga, baik kepada internal dalam hal ini adalah aparat penegak hukum, aparat penegak hukum, seperti kepolisian, kejaksaan, dan hakim pengadilan, maupun kepada eksternal, yaitu kepada masyarakat umum.

\section{b. Faktor Elemen Struktur (Structure)}

Aspek struktur (structure) oleh Friedman dirumuskan sebagai berikut: (Ibid)

"The structure of a legal system consists of elements of this kind. the number and size of courts; their yurisdiction (that is, what kind of cases they hear, and how and why), and modes of appeal from one court to another. Structure also means how the legislature is organized, how many members sit on the Federal Trade

Commission, what a president can (legally) do or not do, what procedures the police department follows, and so on ".

Mengacu kepada rumusan di atas, maka aparat penegak hukum beserta organisasinya, dan DPR merupakan elemen struktur dari sistem hukum. Lembaga DPR sebagai elemen struktur, alat-alat kelengkapan dan anggota DPR merupakan 
${ }^{1}$ Sofian Hadi, ${ }^{2}$ Dini Dewi Heniarti, ${ }^{3}$ Chepi Ali Firman Zakaria, Penerapan Asas Keadilan Terhadap Tindak...

aspek struktur dalam sistem hukum. Diketahui DPR dengan pemerintah mengatur bahwa tindak pidana kekerasan dalam rumah tangga dibuat sebagai delik aduan, sehingga aparat penegak hukum dalam ini akan bersifat pasif ketika terjadi tindak pidana kekerasan dalam rumah tangga.

Berdasarkan hal tersebut, maka menurut Penulis ketika terjadi tindak pidana kekerasan dalam rumah tangga, walaupun korban belum membuat laporan kepada kepolisian, namun demikian kepolisian dapat bertindak sebagai penengah dalam kasus tersebut, dan apabila benar terjadi kekerasan dalam rumah tangga yang membahayakan, maka kepolisian dapat memberikan saran kepada korban untuk membuat laporan agar dapat diproses kasusnya.

\section{c. Faktor Budaya Hukum (Legal Culture)}

Mengenai budaya hukum, Friedman mengartikannya sebagai sikap dan masyarakat terhadap hukum dan sistem hukum, tentang keyakinan, nilai, gagasan, serta harapan masyarakat tentang hukum. Dalam tulisannya Friedman merumuskannya sebagai berikut:

"By this we mean people's attitudes toward law and the legal system- their beliefs, values, ideas, and expectations, in other words, it is that part of the general culture which concerns the legal system".

Budaya patrimonial yang menyebabkan proses pembuatan dan penegakan hukum lebih berorientasi pada kehendakkehendak atas ini telah menimbulkan akibat-akibat buruk bagi perkembangan budaya hukum di tingkat masyarakat. Masih adanya budaya malu kepada korban untuk melaporkan kasus kekerasan dalam rumah tangga dan juga keterbatasan ekonomi serta kebutuhan untuk dilindungi serta disayang orang lain (pasangan) adalah penyebab utama keengganan para korban melaporkan pelaku KDRT. Meskipun kekerasan yang 
${ }^{1}$ Sofian Hadi, ${ }^{2}$ Dini Dewi Heniarti, ${ }^{3}$ Chepi Ali Firman Zakaria, Penerapan Asas Keadilan Terhadap Tindak...

dialami terkadang tergolong

dalam KDRT berat, korban tidak ingin pelaku dihukum atau dipenjara.

Berdasarkan hal tersebut, maka Penulis berpendapat, baik pembuat undang-undang maupun masyarakat tidak menginginkan adanya tindak pidana kekerasan dalam rumah tangga yang berujung pada sanksi penjara, oleh karena itu perlu ada budaya hukum yang harus diarahkan pada pembangunan kesadaran dalam pencegahan terjadinya kekerasan dalam rumah tangga.

Pencegahan tersebut
merupakan upaya preventif
sebagaimana dinyatakan oleh
Philipus M Hadjon yang
menyatakan bahwa tujuan dari
upaya preventif adalah mencegah
terjadinya sengketa. (Philipus M
Hadjon, 1987 : 1). Oleh karena itu,
upaya meminimalisir tindak pidana
kekerasan dalam rumah tangga
sehingga dapat mencegah
terjadinya perceraian itu sendiri
harus menyentuh 3 (tiga) indikator,
yaitu:

$\begin{array}{lr}\text { a. Secara Hukum } & \text { Dengan } \\ \text { Memaksimalkan } & \text { Peran } \\ \text { Subseksi } & \text { Hubungan }\end{array}$

Masyarakat Kepolisian

Bekerja Sama Dengan Dinas

Kependudukan dan KUA;

Menurut Penulis, Undang-

Undang No. 23 Tahun 2004

tentang Penghapusan Kekerasan

Dalam Rumah Tangga secara normatif cukup baik. Dalam ketentuan tersebut jelas diatur bahwa tindak pidana kekerasan dalam rumah tangga dapat diselesaikan secara hukum melalui delik aduan. Sanksi yang diberikan atas adanya tindak pidana kekerasan dalam rumah tangga juga sangat jelas, yaitu pelaku dapat di pidana penjara maksimal 15 (lima belas) tahun atau denda paling banyak Rp 45.000.000,00 (empat puluh lima juta rupiah).

Menurut

Penulis,

ketentuan tersebut telah memberikan kepastian hukum dalam peraturan perundangundangannya, namun mengutip apa yang dikatakan oleh Satjipto Rahardjo, bahwa kepastian hukum bukan terletak kepada peraturan perundangundangannya, namun terletak kepada pelaksanaan undangundang itu sendiri, sehingga 
${ }^{1}$ Sofian Hadi, ${ }^{2}$ Dini Dewi Heniarti, ${ }^{3}$ Chepi Ali Firman Zakaria, Penerapan Asas Keadilan Terhadap Tindak...

menurut Penulis, agar UndangUndang No. 23 Tahun 2004 tentang Penghapusan Kekerasan Dalam Rumah Tangga tidak kehilangan marwah kepastian hukumnya, maka seluruh aparat penegak hukum harus dengan sungguh-sungguh untuk melaksanakan amanat dalam ketentuan tersebut.

Menurut Penulis, upaya tersebut terdapat pada subseksi Hubungan Masyarakat dari Kepolisian bekerja sama dengan Dinas Kependudukan dan KUA yang mempunyai tugas dan tanggung jawab untuk mensosialisasikan semua peraturan perundang-undangan yang berkaitan dengan tindak pidana kekerasan dalam rumah tangga. Sosialisasi tersebut dapat dilakukan baik kepada internal dalam hal ini adalah aparat penegak hukum, aparat penegak hukum, seperti kepolisian, kejaksaan, dan hakim pengadilan, maupun kepada eksternal, yaitu kepada masyarakat umum.

Tujuan sosialisasi tersebut adalah agar aparat penegak hukum dan masyarakat mengetahui hal-hal yang dilarang dalam menjalankan kehidupan berumah tangga. Dengan mensosialisasikan peraturan tersebut, maka aparat penegak hukum mempunyai payung hukum ketika melakukan penindakan terhadap pelaku tindak pidana kekerasan dalam rumah tangga.

b. Program Pemerintah Dalam Pencegahan Terjadinya Kekerasan Dalam Rumah Tangga Sehingga Dapat Mencegah Terjadinya Perceraian;

Dalam upaya mewujudkan keluarga yang sakinah mawaddah warahmah, maka pemerintah juga memiliki tanggung jawab dan peran yang penting untuk mewujudkan hal tersebut. Upaya mewujudkannya dapat dilakukan melalui program-program pencegahan terjadinya kekerasan dalam rumah tangga sehingga dapat mencegah terjadinya perceraian sebagaimana yang dilakukan oleh Pemerintah Provinsi Jawa Barat.

Dalam upaya menekan angka perceraian dan KDRT di 
${ }^{1}$ Sofian Hadi, ${ }^{2}$ Dini Dewi Heniarti, ${ }^{3}$ Chepi Ali Firman Zakaria, Penerapan Asas Keadilan Terhadap Tindak...

Jawa Barat, Gubernur Ridwan Kamil bersama Menteri Pemberdayaan Perempuan dan Perlindungan Anak (PPPA) RI Yohana Susana Yambise meluncurkan program Sekolah Perempuan Capai Impian dan Cita-cita (Sekoper Cinta) di Sabuga, Jl. Tamansari No. 73, Kota Bandung, Minggu 16 Desember 2018. Acara peluncuran ini dirangkai dengan kegiatan pameran/expo UKM perempuan dan Festival Kabupaten/Kota Layak Anak (KLA). Kegiatan ini menjadi bagian dari peringatan Hari Ibu ke-90 Tingkat Nasional Tahun 2018 yang digelar oleh Kementerian PPPA RI. (https://news.detik.com/beritajawa-barat/d-4346125/ridwankamil-gulirkan-sekoper-cinta., diakses pada tanggal 30 Januari 2019).

Sekoper Cinta merupakan wadah bagi perempuan Jawa Barat untuk bertukar pengetahuan dan pengalaman, serta diharapkan bisa meningkatkan kualitas hidup kaum hawa. Ini adalah upaya pemberdayaan perempuan untuk mewujudkan kesetaraan peran, akses, partisipasi, kontrol, dan manfaat antara perempuan dan laki-laki di semua bidang.

c. Peningkatan Kesadaran dan Kepatuhan Hukum Serta Perilaku Masyarakat Melalui Peran Aktif Tokoh Masyarakat.

Konflik rumah tangga bisa terjadi karena adanya ketegangan atau kesulitan di antara dua orang atau lebih akibat adanya perselisihan atau perbedaan pandangan di antara anggota keluarga, misalnya antara suami dan istri. Konflik rumah tangga yang berkelanjutan, sebagai penyebab keluarga tidak harmonis, akan menimbulkan banyak permasalahan rumah tangga, seperti pertengkaran antara suami istri, atau bahkan perceraian. Untuk itu, dibutuhkan cara mengatasi konflik tersebut sebagai antisipasi munculnya permasalahan lain yang lebih rumit.

Berdasarkan hal tersebut, maka peran aktif dari tokoh masyarakat untuk mendukung 
pencegahan terjadinya

kekerasan dalam rumah tangga sangat diperlukan, sehingga masyarakat tersadar bahwa tindak pidana kekerasan dalam rumah tangga sangat tidak dibenarkan. Tokoh masyarakat bekerjasama dengan kepolisian dapat mensosialisasikan kepada masyarakat pentingnya menjaga keutuhan rumah tangga.

Sosialisasi tersebut dapat dilakukan melalui pertemuan warga yang dapat diisi dengan berbagai kegiatan dan juga penyuluhan.

Adapun penyuluhan tersebut dapat berisi:

1) Upaya Menyamakan Visi

Konflik seringkali
terjadi karena adanya
perbedaan pendapat atau
tujuan dari masing-masing
individu. Perbedaan ini jika
tidak ditangani dengan baik
bisa menimbulkan
perselisihan antara suami dan
istri. Oleh karena itu,
sebaiknya pasangan suami
istri mencoba untuk
menyamakan visi terlebih
dahulu. (Ramdani Wahyu
Sururie, 2017: 34-35).

Pada dasarnya, setiap hubungan pernikahan pasti akan mengalami masalah, salah satunya adalah perbedaan pendapat. Namun, pasangan suami istri harus bisa menghadapi permasalahan dalam rumah tangga seperti itu. Dengan berusaha menyamakan visi, pasangan suami istri bisa mengetahui apa tujuan di balik sikap pasangan. Dengan begitu, mereka bisa saling memahami dan mendukung sikap satu sama lain, selama tujuan yang dimaksud memang untuk kebaikan bersama.

2) Upaya Untuk Bernegosiasi

Seperti yang dilakukan dalam organisasi atau hubungan kerja sama, pasangan suami istri juga bisa melakukan negosiasi untuk meraih kesepakatan. Sejatinya hubungan suami istri itu juga merupakan hubungan kerja sama dalam rumah tangga. Jika diibaratkan, suami adalah pemimpin dalam rumah tangga, sedangkan istri 
adalah manajernya. Oleh karena itu, pasangan suami istri harus bisa bekerja sama dan menghindari konflik untuk bisa memimpin rumah tangga ke arah yang diinginkan bersama.

Negosiasi akan berguna untuk mencari jalan tengah dari perselisihan yang dialami. Dengan negosiasi, diharapkan akan ditemukan win-win solution yang bisa cukup memuaskan kedua belah pihak mengatasi masalahnya. Hal ini bisa jadi merupakan cara mengatasi masalah keluarga yang bisa dicoba.

3) Upaya Untuk Terbuka dan Melepaskan Egoisme

Keterbukaan sepasang suami istri dengan bersikap jujur sama lain, dapat membantu mengurai permasalahan yang sedang dihadapi. Mengungkapkan apa yang ada di pikiran dan pendapat-pendapat terhadap konflik yang muncul merupakan tahapan untuk saling memahami perspektif masing-masing.
Memendam pikiran dan membiarkan pasangan mengatasi konflik sendiri hanya akan menjadi bom waktu yang tidak baik bagi kesehatan hubungan rumah tangga. Salah satu penyebab utama konflik keluarga adalah sifat egois dan ingin menang sendiri yang dipertahankan oleh para pasangan. Sifat seperti ini jika dibiarkan justru akan memperburuk konflik yang sedang timbul. Jika salah satu dari pasangan suami istri memiliki sifat egois, maka tidak akan bisa tercapai kesepakatan untuk menyelesaikan konflik dan konflik akan semakin menjadi berlarut-larut. Oleh karena itu, menghilangkan ego di dalam diri masingmasing merupakan solusi paling efektif. Saat seseorang memutuskan untuk menikah sejak awal, seharusnya sudah mulai menyimpan ego dan mengutamakan upaya memahami pasangan demi memelihara keharmonisan rumah tangga. 


\section{PENUTUP}

\section{Kesimpulan}

(1) Penerapan asas keadilan terhadap tindak pidana kekerasan dalam rumah tangga berdasarkan Undang Undang Nomor 23 Tahun 2004 tentang Penghapusan Kekerasan Dalam Rumah Tangga harus dipenuhi 4 (empat) syarat, yaitu equality atau kesamaan baik suami ataupun istri memiliki perlindungan dan akibat hukum yang sama ketika salah satunya melakukan kekerasan dalam rumah tangga. Kedua adalah certainty atau kepastian hukum kepada setiap orang dalam rumah tangga, apa hak-hak dan kewajiban mereka, siapa subjek dan objek. Ketiga adalah arrangement atau pengaturan baik kepada pelaku kekerasan dalam rumah tangga terkait dengan akibat hukum atas tindakan melakukan kekerasan dalam rumah tangga. Keempat adalah implementation atau pelaksanaan dalam setiap penanganan kasus

kekerasan dalam rumah tangga selalu mengikuti amanat dalam UndangUndang No. 23 Tahun 2004 tentang Penghapusan Kekerasan Dalam Rumah Tangga. Namun demikian terdapat kelemahan dalam Undang-Undang No. 23 Tahun 2004 tentang Penghapusan Kekerasan Dalam Rumah Tangga, yaitu tidak adanya pengaturan tentang pemberian restitusi terhadap korban KDRT dan penjatuhan sanksi restitusi kepada pelaku KDRT, sehingga mengakibatkan ketidakadilan bagi korban KDRT, dimana selain menanggung beban penderitaan secara psikis, korban KDRT juga menanggung beban materiil.

(2) Upaya penegakan hukum yang memberikan keadilan bagi para pihak terhadap tindak pidana kekerasan dalam rumah tangga sehingga dapat mencegah terjadinya perceraian adalah 
${ }^{1}$ Sofian Hadi, ${ }^{2}$ Dini Dewi Heniarti, ${ }^{3}$ Chepi Ali Firman Zakaria, Penerapan Asas Keadilan Terhadap Tindak...

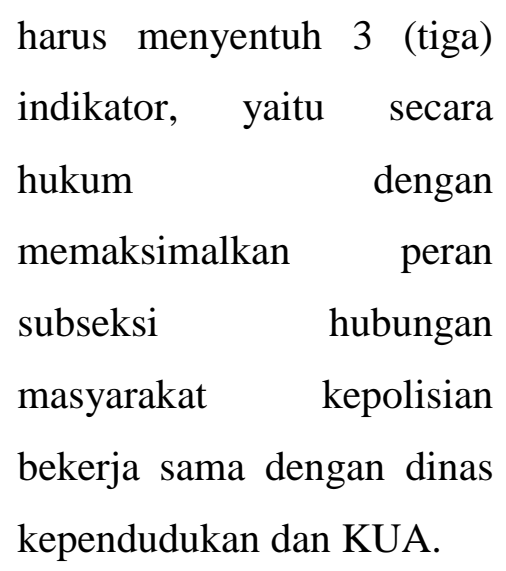

2. Saran

(1) Harus adanya regulasi terkaitpemberian restitusi terhadap korban KDRT dan penjatuhan sanksi restitusi kepada pelaku KDRT, sehingga mengakibatkan ketidakadilan bagi korban KDRT, dimana selain menanggung beban penderitaan secara psikis, korban KDRT juga menanggung beban materiil.

(2) Harus adanya program pemerintah dalam pencegahan terjadinya kekerasan dalam rumah tangga, sehingga dapat mencegah terjadinya perceraian. Terakhir adalah peningkatan kesadaran dan kepatuhan hukum serta perilaku masyarakat melalui peran aktif tokoh masyarakat.

\section{DAFTAR PUSTAKA}

\section{A. Buku :}

Adam Chazawi, Pelajaran Hukum Pidana 2, Penafsiran Hukum Pidana, Dasar Peniadaan, Pemberatan dan Peringanan, Kejahatan Aduan, Perbarengan dan Ajaran Kausalitas, PT Raja Grafindo Persada, Jakarta, 2007.

Barda Nawawi Arief, Buku II, Bunga Rampai Kebijakan Hukum Pidana "Perkembangan Penyusunan Konsep KUHP Baru”, Kencana, 2011, Jakarta.

Bernard L. Tanya, Teori Hukum,Strategi Tertib Manusia Lintas Ruang dan Generasi, Genta Publishing, Yogyakarta, 2010.

Edi Setiadi dan Kristian, Sistem Peradilan Pidana Terpadu dan Sistem Penegakan Hukum di Indonesia, Prenadamedia Group, Jakarta, 2017.

Fatahillah A. Syukur, Mediasi Perkara KDRT (Kekerasan Dalam Rumah Tangga) Teori dan Praktek di Pengadilan Indonesia, CV.Mandar Maju, Bandung, 2011.

I Made Pasek Diantha, Metodologi Penelitian Hukum Normatif Dalam Justifikasi Teori Hukum, Prenada Media Group, Jakarta, 2016.

Lawrence M Friedman. Legal Theory, Columbia University Press, New York, 1967.

Philipus M Hadjon, Perlindungan Hukum Bagi Rakyat di 
${ }^{1}$ Sofian Hadi, ${ }^{2}$ Dini Dewi Heniarti, ${ }^{3}$ Chepi Ali Firman Zakaria, Penerapan Asas Keadilan Terhadap Tindak...

Indonesia, PT. Bina Ilmu, Surabaya, 1987.

Ramdani Wahyu Sururie, Darurat Perceraian Dalam Keluarga Muslim Indonesia, Lembaga Penelitian dan Pengabdian Kepada Masyarakat, Universitas Islam Negeri Sunan Gunung Djati Bandung, Bandung, 2017.

Rodliyah dan Salim HS, Hukum Pidana Khusus: Unsur dan Sanksi Pidananya, Rajawali Pers, Depok, 2017.

Soerjono Soekanto dan Sri Mamudji, Penelitian Hukum Normatif, Raja Grafindo Persada, Jakarta, 2006.

Sri Rahayu Oktoberina, Butir-butir Pemikiran Dalam Hukum, Refika Aditama, Bandung, 2008.

\section{B. Peraturan Undangan:}

\section{Perundang-}

Undang-Undang Dasar Negara Republik Indonesia Tahun 1945 (Lembaran Negara Republik Indonesia Tahun 2006 Nomor 14).

Kitab Undang-Undang Hukum Pidana.

Undang-Undang Nomor 23 Tahun 2004 tentang Penghapusan Kekerasan Dalam Rumah Tangga.

Undang-Undang Nomor 31 Tahun 2014 Tentang Perubahan Atas Undang-Undang Nomor 13 Tahun $2006 \quad$ Tentang Perlindungan Saksi dan Korban.
Undang-Undang Nomor 17 Tahun 2016 Tentang Perubahan Kedua Atas Undang-Undang Nomor 23 Tahun $2002 \quad$ Tentang Perlindungan Anak.

\section{Internet :}

Lembar Fakta Catatan Tahunan (CATAHU) Komnas Perempuan Tahun $2017 . \quad$ Lihat: https://www.komnasperempuan. go.id/file/pdf_file/2017\%20Siar an\%20Pers/Lembar\%20Fakta\% 20Catahu\%202017.pdf., diakses pada tanggal 4 Oktober 2018.

Catatan Tahunan CATAHU Komnas Perempuan Tahun 2018, Jakarta, 7 Maret 2018, Hlm. 1. Lihat: https://www.komnasperempuan. go.id/file/pdf_file/2018/SIARA N\%20PERS\%202018/Lembar\% 20Fakta\%20Catahu\%207\%20M aret\%202018.pdf., diakses pada tanggal 4 Oktober 2018.

https://news.detik.com/berita/3867106 /lbh-apik-terima-aduan-308kdrt-selama-2017., diakses pada tanggal 4 Oktober 2018. 